\title{
Phenotypic characterisation of peripheral blood lymphoid cells in people exposed to fibrous zeolite
}

\author{
M ÖZESMI, ${ }^{3}$ A KARLSSON-PARRA, ${ }^{2}$ G HILLERDAL, ${ }^{3}$ U FORSUM $^{2}$ \\ From the Department of Internal Medicine, ${ }^{1}$ University of Erciyes, Kayseri, Turkey, and Institute of Clinical \\ Bacteriology ${ }^{2}$ and Department of Lung Medicine, ${ }^{3}$ Akademiska Sjukhuset, Uppsala University, Sweden
}

ABSTRACT Among inhabitants of the village of Karain in Turkey there is an extremely high inci- $\bar{\omega}$ dence of malignant mesothelioma, most probably due to exposure to erionite, which is a fibrous $\bigcirc$ zeolite and similar in appearance and properties to asbestos. This mineral may be found in the dust $\frac{\mathbb{}}{3}$ in the village. To characterise possible disturbances in the immune system of people exposed to $\vec{\omega}$ fibrous zeolite, a phenotypic characterisation of lymphoid cells in the peripheral blood of $74 \mathrm{immi-}$ grants to Sweden from Karain was performed. Compared with normal controls, the mean percentages of Leu $4^{+}$cells (Pan-T) and Leu $3 \mathrm{a}^{+}$cells ("helper/inducer" $\mathrm{T}$ cells) were significantly $\mathscr{E}^{\circ}$ decreased, whereas the mean percentage of Leu $2 \mathrm{a}^{+}$cells ("suppressor/cytotoxic" $\mathrm{T}$ cells) was $ᄋ$ normal, leading to a significant reduction of the Leu $3 \mathrm{a} / \mathrm{Leu} 2 \mathrm{a}$ subset ratio. The percentage of $\mathrm{B}-$ cells (Leu $12^{+}$cells) was significantly increased, whereas the percentages of both HLA-DR ${ }^{+}$and HLA-DQ ${ }^{+}$cells were normal. The percentage of natural killer cells (NK) and killer (K) cells as defined by the monoclonal anti-Leu 7 and anti-Leu $11 \mathrm{~b}$ were also normal. These findings indicate that exposure to fibrous zeolite causes a numerical imbalance between the two phenotypically $\mathbb{\mathbb { D }}$ different $\mathrm{T}$ cell subsets similar to that seen in asbestos exposed individuals.

Inhabitants of the village of Karain in Anatolia have an extremely high incidence of malignant mesothelioma, ${ }^{1}$ probably caused by the inhalation of fibrous zeolite (erionite) which is present in the environment. ${ }^{12}$ The mineralogical characteristics ${ }^{34}$ and the deleterious effects on human health are similar to those of asbestos. ${ }^{5}$ In asbestosis several immunological stigmata such as hypergammaglobulinaemia (IgG), in vitro cellular immune dysfunction, and abnormal peripheral blood levels of different immunoregulatory $T$ cell subsets have been reported. ${ }^{67}$

Since an intact immunoregulatory network is thought to be of great importance for effective surveillance against tumours, such immunological derangements are of interest in the search for pathogenetic mechanisms underlying the development of mesothelioma. An experimental study on rats suggested that dust from Karain may affect the lymphoid system. ${ }^{8}$ To our knowledge, however, no study of the immunological status of people exposed to erionite has been reported previously.

In Stockholm there are about 150 individuals who were born in Karain or lived there for many years but

Accepted 28 May 1986 have now immigrated to Sweden. Among the imme grants from Karain there have been several deathis due to malignant mesothelioma, and more are to be expected. ${ }^{9}$ The aim of the present study was to investigate whether there are any aberrations in the number of lymphoid cells in the peripheral blood of these people and if so to correlate them with radiographic findings, a family history of mesothelioma, and to future development of disease, particularly mesothelioma.

\section{Material and methods}

The names and addresses of individuals from the village of Karain now living in Stockholm were obtained from a list of an earlier study ${ }^{9}$ and completed with personal information from some of the people in the group who were invited to participate in the present study. The subjects underwent clinical examination and chest radiography and their history (personal and familial) was taken. Blood samples for investigation of different lymphoid cells and for determination of the concentrations of albumin, immunoglobulins, and orosomucoid were taken. 
CONTROLS

Healthy blood donors were used as controls.

PERIPHERAL BLOOD MONONUCLEAR CELLS

Mononuclear cells in heparinised peripheral blood were isolated by standard methods on a FicollHypaque density gradient. The cells were then washed three times in phosphate buffered saline (PBS) containing $0 \cdot 1 \%$ bovine serum albumin (BSA) at $10^{6}$ cells $/ \mathrm{ml}$. About $10 \mu \mathrm{l}$ of the cell suspension was dropped into each well of a multiple well microscope slide. The slides were air dried at $+37^{\circ} \mathrm{C}$ for one hour and then stored at $-70^{\circ} \mathrm{C}$. After storage the cell preparations were immediately fixed in acetone diluted $1: 1$ with water $\left(+4^{\circ} \mathrm{C}\right)$ for one minute and finally fixed in $100 \%$ acetone $\left(+4^{\circ} \mathrm{C}\right)$ for five minutes before staining. 10

\section{ANTISERA AND OTHER REAGENTS}

The murine monoclonals denoted anti-Leu 4, -Leu 2a, -Leu 3a, -Leu 7, -Leu 11 b, -Leu 10, -Leu 12, and antiHLA-DR were all obtained from Becton Dickinson (Sunnyvale, Calif). Anti-Leu 4 defines all peripheral $T$ cells, ${ }^{11}$ whereas anti-Leu $2 \mathrm{a}$ defines the "suppressor/cytotoxic" T cell subset. ${ }^{12}$ Anti-Leu 3a reacts with the "helper/inducer" $\mathrm{T}$ cell subset, ${ }^{12}$ but also reacts with some cells of the monocyte/macrophage lineage ${ }^{13}$ in prefixed cell samples. Anti-Leu 12 defines all peripheral B cells (T C Meeker et al, in preparation). Anti-Leu 10 is specific for the HLA-DQ antigen, a human D region associated antigen, ${ }^{14}$ that differs from the HLA-DR antigen recognised by the anti-HLA-DR monoclonal. ${ }^{15}$ The human $\mathrm{D}$ region associated antigens are expressed in B lymphocytes, monocytes/ macrophages, and activated $T$ cells. Anti-Leu 7 and anti-Leu $11 \mathrm{~b}$ monoclonals are thought to define the major NK and K cell subsets. ${ }^{1617}$

The FITC conjugated goat antimouse antibody was obtained from the National Bacteriological Laboratory (SBL), Sweden. Biotinylated horse antimouse IgG, avidin $\mathrm{DH}$, and biotinylated horseradish peroxidase H ("ABC" kit) were obtained from Vector laboratories (Burlingame, Calif). 3-Amino-9ethylcarbazole was obtained from Sigma (St Louis, Mo).

\section{IMMUNOENZYME STAINING}

After the fixation procedure the slides were washed in PBS (pH 7.4) for five minutes. The subsequent incubations were carried out sequentially at room temperature and the slides were washed for five minutes in the PBS buffer between each step. Endogenous peroxidase was blocked by incubation in $0.3 \mathrm{H}_{2} \mathrm{O}_{2}$ for 15 minutes. The cell preparations were then incubated for 30 minutes in humid atmosphere with $25 \mu$ l por- tions of monoclonal antibodies (dilution 1/32 for anti--Leu 4, -Leu 2a, -Leu 3a, -Leu 10, and -Leu 12, and 1/128 for anti-HLA-DR in PBS containing 4\% BSA). Biotinylated horse-antimouse IgG (dilution $1 / 400)$ was allowed to react with the cell preparation for 30 minutes. A complex of $5 \mu \mathrm{l}$ of avidin $\mathrm{DH}$ $(10 \mathrm{mg} / \mathrm{ml})$ and of $5 \mu \mathrm{l}$ of biotinylated horseradish peroxidase $\mathrm{H}(5 \mathrm{mg} / \mathrm{ml})$ in $400 \mu$ l of PBS was then layered on the cell preparation for 30 minutes. The peroxidase reaction was developed with use of a carbazole containing buffer for 15 minutes. The cell preparations were exposed to haematoxylin for nuclear staining and mounted in Kaiser's glyceringelatin (Merck, Darmstadt). The percentage of positive cells with a marginal membrane staining pattern $^{11}$ was determined by counting 200-500 mononuclear cells in a routine light microscope.

\section{IMMUNOFLUORESCENCE STAINING}

When using first step monoclonals of IgM class (antiLeu 7 and anti-Leu $11 \mathrm{~b}$ antibodies) FITC conjugated goat antimouse Ig was used as second step reagent. The cell preparations were incubated for 30 minutes with $25 \mu$ l portions of monoclonal antibodies (dilution $1 / 80$ for Leu 7 and 1/20 for Leu 11 b in PBS containing 4\% BSA), washed for five minutes in PBS and then incubated with FITC antimouse immunoglobulin (dilution $1 / 320$ in PBS containing 4\% BSA) for 30 minutes. After being washed in PBS for 10 minutes, the cell preparations were mounted in PBS-glycerine. The cells were examined under a Leitz epifluorescence microscope. The percentage of positive cells was determined by counting 200 cells. The primary antibody was omitted for the negative controls.

\section{STATISTICAL METHODS}

Student's $t$ test was used for tests of significance.

\section{Results}

Ninety four individuals responded to the invitation and participated in the study. In 74 (38 women and 36 men) blood samples were taken. Ten of these 74 had lived in Karain for less than ten years, 38 for ten to 20 years, and 26 for over 20 years. Seven showed radiological pulmonary abnormalities (pleural plaques).

The serum concentrations of albumin, IgG, IgA, and IgM were within the normal range (table). Neither sex, radiological abnormalities, nor the duration of residence in Karain showed any correlation with the serum immunoglobulin concentrations. The plasma orosomucoid concentration was slightly raised in those aged over $45(n=7)$ (mean value $1 \cdot 2$, 2SD 0.19).

As seen in fig 1 , the mean percentage of Leu $4^{+}$cells 
Serum concentrations of albumin, immunoglobulins, and plasma orosomucoid in the Karain group. Normal range is given for comparison

\begin{tabular}{|c|c|c|c|}
\hline & \multicolumn{2}{|l|}{ Karain group } & \multirow[b]{2}{*}{ Normal range $(\mathrm{g} / \mathrm{l})$} \\
\hline & No of samples & $\begin{array}{l}\text { Mean value and } \\
\operatorname{SEM}(g / l)\end{array}$ & \\
\hline $\begin{array}{l}\text { Serum albumin } \\
\text { Serum IgG } \\
\text { Serum IgA } \\
\text { Serum IgM } \\
\text { Plasmaorosomucoid }\end{array}$ & $\begin{array}{l}71 \\
71 \\
58 \\
58 \\
71\end{array}$ & $\begin{array}{l}45.8(0.45) \\
11.7(0.25) \\
2.05(0.11) \\
1.39(0.07) \\
1.0(0.03)\end{array}$ & $\begin{array}{l}37-52 \\
7-15 \\
0 \cdot 8-3 \cdot 8 \\
0 \cdot 4-2 \\
0 \cdot 5-1\end{array}$ \\
\hline
\end{tabular}

was lower $(p<0.01)$ and that of B cells (Leu $\left.12^{+}\right)$ higher $(p<0.05)$ in the Karain group than in the normal controls. The mean percentages of HLA-DR and HLA-DQ (Leu 10) expressing cells did not differ from those in the control group. NK/K cell numbers as defined by the anti-Leu 7 and anti-Leu $11 \mathrm{~b}$ monoclonals were also normal.

The percentage of Leu $3 \mathrm{a}^{+}$cells (helper/inducer $\mathrm{T}$ cells) was significantly lower $(p<0.01)$ in the Karain group than in the controls, whereas that of Leu $2 \mathrm{a}^{+}$ cells (suppressor/cytotoxic $T$ cells) was normal. Thus there was a significant decrease $(p<0.05)$ in the Leu 3a/Leu 2a ratio in the Karain group (fig 2).

No correlation was found between the percentages of different lymphoid cells and age, sex, family history of mesothelioma or duration of residence in the village of Karain. People with chest $x$ ray abnormalities, however, showed a more profound reduction of Leu $3 a^{+}$cells, leading to a lower Leu $3 a / L e u ~ 2 a$ ratio. These differences from the rest of the Karain group were not statistically significant.

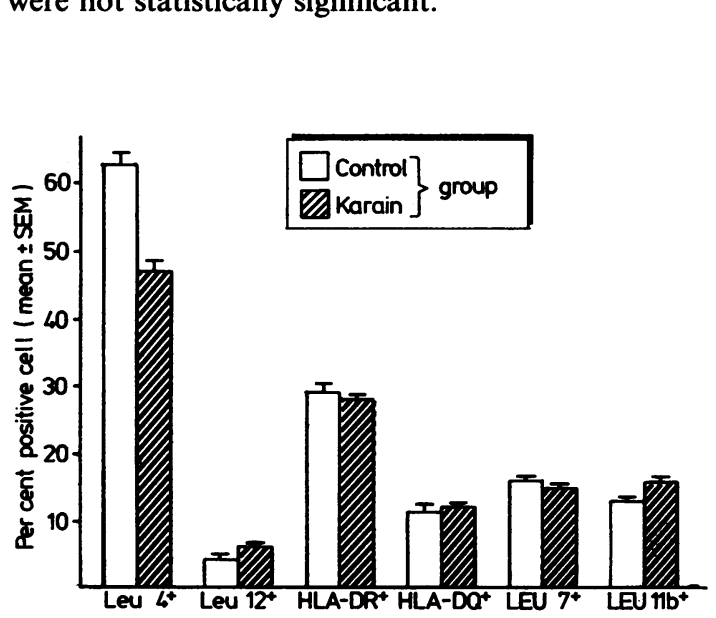

Fig 1 Per cent positive cells (mean SEM) of different phenotypes in peripheral blood of Karain group ( $n=74$ for Leu 1, Leu 12, HLA-DR, and HLA-DQ, $n=15$ for Leu 7 and Leu 11b) and control group $(n=10$ for all monoclonals examined).

\section{Discussion}

Earlier epidemiological studies have shown that environmental exposure to fibrous zeolite can cause pleural plaques, pleural calcification, pleural and peritoneal mesothelioma, and pulmonary fibrosis, ${ }^{1518}$ diseases similar to those caused by exposure to asbestos. Experimental exposure of animals to erionite has resulted in mesothelioma, ${ }^{819}$ which supports these epidemiological data.

In asbestosis several immunological derangements have been shown, including a numerical imbalance between different immunoregulatory $T$ cell subsets. ${ }^{20}$ In people exposed to erionite, however, no such immunological studies have been reported. Our finding of a reduced number of Leu $3 \mathrm{a}^{+}$cellg (helper/inducer $\mathrm{T}$ lymphocytes) leading to a decrease in the Leu 3a/Leu 2a ratio is, to our knowledge, the

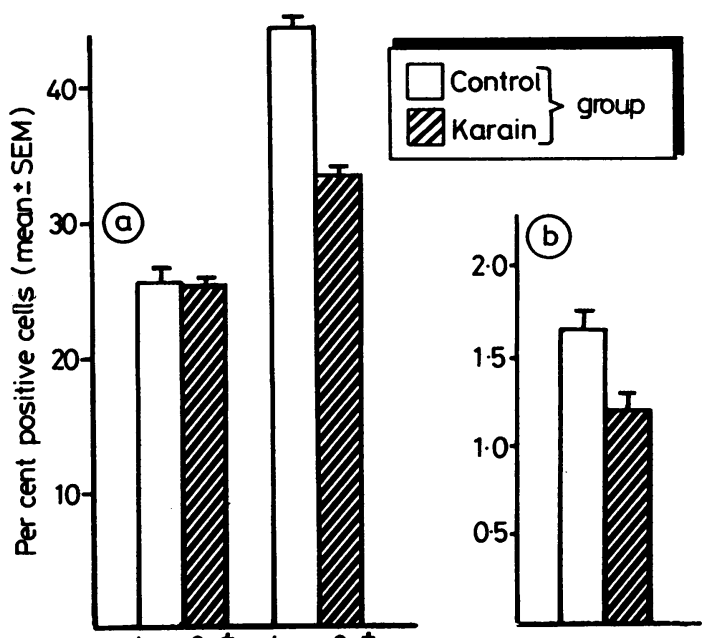

Fig 2 (a) Per cent positive cells (mean SEM) of Leu $3 a$ and Leu $2 a$ phenotype in peripheral blood in Karain group $(n=74)$ and control group $(n=34)$. (b) Leu $3 a /$ Leu $2 a$ ratio in Karain group $(n=74)$ and control group $(n=34)$. 
first evidence of a $\mathrm{T}$ cell subset derangement in people exposed to erionite. This finding is similar to the derangement in $\mathrm{T}$ cell subsets found in individuals exposed to asbestos.

Since an intact immunoregulatory network is thought to be of great importance for effective surveillance against tumours, such observed imbalance between different immunoregulatory $T$ cell subsets are of interest. It is still unclear, however, whether this imbalance is of aetiological importance for the development of mesothelioma, or if it represents a secondary epiphenomenon. Further clinical and immunological follow up of this group might shed some light on this particular question.

We thank the Swedish Medical Research Council and the Swedish Union Against Heart and Lung Diseases for their support.

\section{References}

1 Baris YI, Sahin AA, Özesmi M, et al. An outbreak of pleural mesothelioma and chronic fibrosing pleurisy in the village of Karain/Urgup in Anatolia. Thorax 1978;33:184-92.

2 Elmes PC. Fibrous minerals and health. Journal of the Geological Society of London 1980;137:525-35.

3 Förster H. Eine mineralogisch-petrograpohische Untersuchung uber mögliche Ursachen von Mesotheliomen in Kappadokien/Turkei. Zentralblatt für Arbeitsmedizin 1982;32: 18-27.

4 Helfferrich F. A simple identification for zeolites (molecular sieves). American Mineralogist 1964;49:1752-4.

5 Artvinli M, Baris YI, Environmental fiber-induced pleuropulmonary disease in an Anatolian village: and epidemiological study. Arch Environ Health 1982;37:177-81.

6 Preger L. Asbestos-related disease. London: Grune and Stratton, 1978:23-6.

7 de Shazo RD, Nordberg BA, Baser Y, Bozelka B, Weill H, Salvaggio J. Analysis of depressed cell-mediated immunity in asbestos workers. J Allergy Clin Immunol 1983;75:418-24.

8 Özesmi M, Patiroghe TE, Hillerdal G, Özesmi C. Peritoneal mesothelioma and malignant lymphoma in mice caused by fibrous zeolite. Br J Ind Med 1985;42:746-9.

9 Boman G, Schubert V, Svane B, et al. Malignant mesothelioma in Turkish immigrants residing in Sweden. Scand $J$ Work Environ Health 1982;8:108-12.

10 Karlsson-Parra A, Forsum U, Klareskog L, Sjöberg O. A simple immunoenzyme batch staining method for the enumeration of peripheral human $\mathrm{T}$ lymphocyte subsets. $J$ Immunol Methods 1983;64:85-90.

11 Ledbetter JA, Evans RL, Lipinski M, Cunningham-Rundles C, Good RA, Herzenberg LA. Evolutionary conservation of surface molecules that distinguish $T$ lymphocyte helper/inducer and $\mathrm{T}$ cytotoxic/suppressor subpopulations in mouse and man. $J$ Exp Med 1981;153:310-23.

12 Engleman EG, Benike CJ, Glickman E, Evans RL. Antibodies to membrane structures that distinguish suppressor-cytotoxic and helper T lymphocyte subpopulations block the mixed leucocyte reaction in man. $J$ Exp Med 1981;153:193-8.

13 Wood GS, Warner NL, Wranke RA. Anti Leu 3/Tu antibodies react with cells of monocyte/macrophage and Langerhans lineage. J Immunol 1983;131:212-6.

14 Brodsky FM. A matrix approach to human class II histocompatibility antigens: reactions of four monoclonal antibodies with the products of nine haplotypes. Immunogenetics 1984;19:179-94.

15 Lampson LA, Levy R. Two populations of Ia-like molecules on a human B-cell line. J Immunol 1980;125:293-9.

16 Abo T, Balch CM. A differentiation antigen of human NK and $K$ cells identified by a monoclonal antibody (HNK-1). J Immunol 1981;127:1024-9.

17 Phillips JH, Le AM, Lanier LL. Natural killer cells activated in a human mixed lymphocyte response culture identified by expression of Leu-12 and class II histocompatibility antigen. $J$ Exp Med 1984;159:993-1008.

18 Casey KR, Shigeoka JW, Rom WN, Moatamed F. Zeolite exposure and associated pneumoconiosis. Chest 1985;87:837-40.

19 Maltoni C, Mikardo F, Moviso L. Pleural mesothelioma in Sprague-Dawley rats by erionite: first experimental evidence. Environ Res 1982;29:238-44.

20 de Shazo RB, Hendrich AJ, Diem JE, et al. Immunologic aberrations in asbestos cement workers: dissociation from asbestosis. J Allergy Clin Immunol 1983;72:454-61.

\section{Destruction of manuscripts}

From 1 July 1985 articles submitted for publication will not be returned. Authors whose papers are rejected will be advised of the decision and the manuscripts will be kept under security for three months to deal with any inquiries and then destroyed. 